\title{
RECIPROCITY FOR LETTERS ROGATORY UNDER THE JUDICIAL CODE
}

To the end that all necessary evidence may be available in an American forum, provision must be made to obtain depositions of witnesses who are abroad and unable to testify personally. Historically, litigants in the federal courts of the United States have been afforded two means of obtaining such depositions: commissions, and letters rogatory. ${ }^{2}$ A party who desires the testimony of an absent witness may request the court to commission an official-ordinarily an American consular officer-in the foreign country to talke the deposition. ${ }^{3}$ A difficulty with this procedure, however, is that some nations will not permit commissioners to be appointed by American courts." And

1. The scope of this Note is limited to the use and execution of letters rogatory in the federal courts. The use of depositions under the Federal Rules of Civil Procciure is treated in 2 Mfoore, Federal Practice 2435 at siq. (1st ed. 1938). Federal deposition

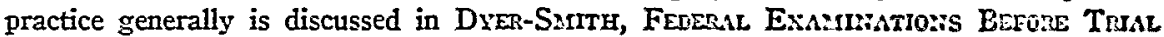
(1939), and in the earlier WeErs, LAW of Deposrrrons (1ES0). Some practical aspests of taking depositions abroad are discussed by Heilpern, Proctring Exidcnec Alroad, 14 TULANE L. REv. 29 (1939), and a thorough summary of the procedures and problems involved in taking such depositions is found in Note, 96 U. of PA. L. Rsv. 241 (1947).

2. "There is a broad distinction between the execution of a commission and the procurement of testimony by the instrumentality of letters rogatory or requisitory. In the former case, the rules of procedure are established by the court issuing the commission, and are entirely under its control. In the latter, the methods of prosedure must, from the nature of the case, be altogether under the control of the foreign tritunal which is appealed to for assistance in the administration of justice. We cannot exceute our own laws in a foreign country nor can we prescribe conditions for the performance of a request which is based entirely upon the comity of nations, and which, if granted, is altogether ez gratia." WeEss, LAW of Depositions 151 (1880). The State Department recognizes a similar distinction between commissions and letters rogatory. 2 Hacr:WORTH, Digest OF INTERNational LAw 98 (1941).

3. When a court commissions an individual to take a deposition it is, in effect, elothing that person with its judicial authority. Hence commissions have been tormed depositions dedimus potestatcon- "we have given the power." Until enactment of the Federal Rules of Civil Procedure in 1938, depositions dedinns fotestaton were authorizcd by the old judicial provisions. REv. Stat. $\$ \$ 66$ (1875), 28 U.S.C. $\$ 644$ (1946). This section was reflected in the Rules. FED. R. Crv. P., 26 it scq. The form of a typical commission is given in 2 MIOORE, FEDERAL Practice, 2517-S (1st ed. 1938).

In naming a commissioner the court is not required to chouse a consular officer. Id. at 2547. Consular officials are required to take depositions when cammissioned to do so. 34 Stat. 101 (1906), 22 U.S.C. $\$ 1195$ (1946). If the cummission cannot te executed, they are to return it to the court from which it issued. 4 HAcsworta, op. cil. sustra note 2 , at $\$ 4-5$.

4. The attitudes of foreign nations towards the use of commissions within thair borders vary from complete indifference to absolute refusal to permit the practice. For a complete summary of the appropriate procedures for taking depositions in varicus foreign countries, see DyER-SuIrH, op. cit. supra note 1, bl. III. Eefore World War II letters rogatory were the only technique available by which testimony could be obtained in the Union of Soviet Socialist Republics, Switzerland and Japan, 2 Moone, FruzrnL 
even in many of those countries where recognition is given to the American appointment, the commissioner has no power to compel a witness to appear. Consequently, the federal courts often can obtain desired evidence only by enlisting the assistance of the foreign government through its own judiciary. This may be done by the device of letters rogatory $:^{b}$ on the motion of a party, the forum issues a document addressed to the appropriate foreign court requesting that the latter take the deposition of a witness under its jurisdiction, or that it commission an official to do so. Invariably the document concludes with a promise of reciprocity in honoring similar requests made by courts of the foreign country. ${ }^{8}$ Letters rogatory are a device of direct international judicial cooperation and depend, for their effectiveness, upon comity.

Fostering of comity, as well as integrity in keeping the promises made, apparently demands that if federal courts are to issue letters rogatory, the United

PRACTICE 2551 n.2 (1st ed. 1938), and some South American countries are reluctant to cooperate with foreign commissioners. Heilpern, supra note 1, at 34 n.6.

Reciprocal agreements with many countries specifiy particular instances when American consular officials may take depositions in the foreign nations.

5. This presents the biggest problem arising in the use of commissions, for the commission cannot be executed if the witness is unwilling to testify voluntarily. A few countries do empower commissioners named by foreign courts to summon unvilling witnesses. As an example, see the English statute, Foreign Tribunals Evidence Act, 1856, 19 \& 20 VICT., c. 113. And see DYER-SMITH, op. cit. supra note 1, \$63; STERN, Getring the Evidence $\$ 156$ (1936); Heilpern, supra note 1, at 36.

6. "Letters rogatory are the medium, in effect, whereby" one country, speaking through one of its courts, requests another country, acting through its own courts and by methods of court procedure peculiar thereto and entirely within the latter's control, to assist the administration of justice in the former country; such request being made, and being usually granted, by reason of the comity existing between nations in ordinary peaceful times." The Signe, 37 F.Supp. 819, 820 (E.D. La. 1941). Since the assistance of the foreign court is given as a matter of comity, it is usually necessary that the request for that aid be a formal one-a letter rogatory-coming from the court in which the evidence is desired. Thus, where a commissioner cannot compel the attendance of an unwilling witness the American forum must ordinarily make the request to the foreign judiciary with jurisdiction over the witness.

The medium of letters rogatory has many disadvantages, among which are those of determining the proper foreign court to which the letters must be addressed, obtaining translations of the depositions and of any interrogatories which may be sent, and the long delay which may be involved. 8 Wigmore, Evidence $\$ 2195 \mathrm{~b}$ (3d ed. 1940); see also 2 Moore, Federal. Practice 2553-5 (1st ed. 1938).

The procedure for the use of letters rogatory between the United States and the Union of Soviet Socialist Republics was defined by diplomatic agreement. 167 LEAGUE of NATIONS Treaty SerIes 304 (1936), 49 STAT. 3840 (1936).

7. It is advisable that the party to an action who desires the deposition of a witness abroad consult the State Department for advice as to the most effective means of obtaining the assistance of the judiciary of the foreign country. Practical suggestions in the use of letters rogatory are found in 2 Moore, Federal Practice 2548-55 (1st ed. 1938). The complete form of typical letters rogatory is given, id. at 2549; 3 BENEDICT, Adumantr $\S 400$ (6th ed. 1940).

8. The customary form of this promise is: "And we shall be ready and willing to do the same for you in a similar case when required." 3 BENEdict, AdMIRALTY 101 (6th ed. 1940). 
States make equivalent provision for honoring the letters of foreign courts. Yet treatment of the two has been far from parallel. In the past, the federal courts and Congress have ungenerously refused to accord foreign letters the same treatment which foreign courts have been requested to extend to American letters. This anomaly has recently been corrected, ${ }^{10}$ but the mincing steps toward that rather simple goal provide a revealing vignette of legislature and judiciary "in action."

Prior to 1938 the only statute applicable to issuance of letters rogatory impliedly authorized their issuance by federal courts only in suits "in which the United States are parties or have an interest." 11 Nevertheless, letters rogatory would be issued, at the discretion of the trial court, on the motion of a party in any civil suit. 12 With certain qualifications they were also available to the defendant ${ }^{13}$ in a criminal action. ${ }^{14}$ The federal courts found no difficulty in

9. Treaties of international judicial assistance are common, particularly among the nations of Europe Many of these are listed in 33 A3r. J. Irr'L L. 119-2S (Supp. 1939). Several proposals have been made for international agreements to improve the cooperation in judicial matters. See Committee of Experts for the Progressive Codification of Int'l Law, Connmusnication of Judicial and Extra-Iudicial Acts in Pesal Matters and Letters Rogatory in Pental Mafters, 22 Axr. J. INT'z L. 46 (Special Supp. 1923) (Schücl:ing, rapporteur) and the Draft Convention on Judicial Assistance sponsored by the Harvard Research in International Law, 33 Axr. J. INr'L L. 35 (Supp. 1939). The United States has refused to enter into such agreements, presumably because the diverse deposition practices of the forty-eight states would not lend themselves to such agreements. International judicial assistance agreements are discussed in Note, 96 U. of PA. L. Rew. $241,252-5$ (1947).

10. The last step was taken in Pub. L. No. 72, 81st Cong., 1st Sess., $\$ 93$ (1fay 24, 1949). See note 25 infra.

11. Rev. Stat. $\$ 875$ (1878), 28 U.S.C. $\$ 653$ (1946). This section was repealed by enactment of the new Judicial Code, 28 U.S.C.A. $\$ 17 \$ 1$ (1948).

12. "[A]s this method of getting testimony is most necessary in countries which refuse to compel the attendance of witnesses under commissions, $I$ think we ought not to suppose that Congress intended to limit the power of the court." De Villeneuve v. Morning Journal Ass'n, 206 Fed. 70 (S.D.N.Y. 1913).

See note 16 infra.

13. The use of depositions is not extended to the Government in criminal actions because of the defendant's constitutional right to have adverse witnesses personally appear in court. Blackmer v. United States, 49 F.2d 523, 530 (App.D.C. 1931), off'd on other grounds, 284 U.S. 421 (1932). The Attorney General, however, has statutory power to compel the return to this country of any witness who is a citizen or resident of the United States who is abroad and whose testimony is desired at the trial of a criminal action. 44 Stat. $\$ 35$ (1926), as amended, 28 U.S.C.A. $\$ \$ 1783-4$ (194\$). This power has been upheld. Blackmer v. United States, 284 U.S. 421 (1932) (citizen).

14. ReV. STAT. $\$ 866$ (1875), 28 U.S.C. $\$ 644$ (1946), authorized the use of the commission "in any case where it is necessary, in order to prevent a failure or delay of justice," and the word "case" was interpreted to include criminal actions. United States v. Dunn, 55 F.Supp. 535 (S.D.N.Y. 1944); United States v. Cameron, 15 Fed. 794 (C.C.E.D.Mo. 1883). Since commissions were thus available in criminal actions, defendants were permitted to employ letters rogatory to obtain those depositions when commissions were inadequate, provided that the evidence sought was stown to to material and that the use of the deposition was necessary to prevent a failure or delay of 
justifying this broad use of the procedure. Their authority was envisioned as stemming from an "inherent power" of the courts to issue letters ${ }^{16}$ whenever other methods of obtaining desired testimony were inadequate. ${ }^{10}$ Statutory authorization was deemed unnecessary.

On the other hand, the letters rogatory of other nations were honored only if they strictly conformed to statutory standards. Until recently Section 701 of Title 28 of the United States Code ${ }^{17}$ limited the honoring of foreign letters to an action for the recovery of money or property that was pending in the court of a nation which was at peace with the United States and which was a party to, or had an interest in, the suit. Obviously these restrictions precluded the honoring of foreign letters rogatory issuing from most civil suits, and all of those arising out of criminal actions. ${ }^{18}$ Yet the federal courts refused to supplement the statutory provision by invoking the "inherent power" rationale which had

justice. United States v. Hoffman, 24 F.Supp. 847 (S.D.N.Y. 1938). Contra: Luscnberg v. United States, 45 F.2d 497 (4th Cir. 1930), cert denied, 283 U.S. 820 (1931).

15. De Villeneuve v. Morning Journal Ass'n, 206 Fed. 70 (S.D.N.Y. 1913); In re Pacific Railway Commission, 32 Fed. 241,256 (C.C.N.D.Cal. 1887); 1 GreEnLEAF, EVIDENCE \$2195d, n.1 (3d ed. 1940).

16. Letters rogatory are available to a party only when it is shown to the satisfaction of the trial court that the desired testimony could not satisfactorily be obtained by commission. Gross v. Palmer, 105 Fed. 833 (C.C.N.D.I11. 1900); Nelson v. United States, 17 Fed. Cas. 1340, No. 10,116 (C.C.D.Pa. 1816) ; 2 Jones, The Law of Evinence: IN Crvil Cases $\$ 700$ (4th ed. 1938). And see Fen. R. Crv. P., 28(b). A corollary would seem to be that letters rogatory will not be granted until the issues are sufficiently framed to permit determination of whether the testimony sought is actually necessary to the trial, or unless it is shown that the testimony might otherwise be lost. Midwest Mig. Co. v. Staynew Filter Corp., 11 F.Supp. 705, 708 (W.D.N.Y. 1935). When it is apparent that a deposition is necessary and that the foreign country will not recognize a commission, letters rogatory will issue. In re Bedford Watch Co., 18 F.Supp. 1009 (S.D.N.Y. 1937) ; Nelson v. United States, supra.

17. Rev. STAT. $\$ 4071$ (1875), 28 U. S. C. $\$ 701$ (1946); Iu re Letters Rogatory from Examining Magistrate of Tribunal of Versailles, France, 26 F.Supp. 852 (D. Md. 1939). The last sentence of REv. STAT. $\$ 875$ (1878), 28 U.S.C. $\$ 653$ (1946), provided that when letters rogatory were addressed by a foreign court to any district court of the United States, the commissioner designated by the district court could compel the witness to appear and testify. This sentence was deemed not to extend the meaning of the Section cited in the text. In re Letters Rogatory from Examining Magistrate of Tribunal of Versailles, France, 26 F.Supp. 852 (D. Md. 1939).

18. In re Letters Rogatory of Republic of Colombia, 4 F.Supp. 165 (S.D.N.Y. 1933) (an investigation of breach of Colombian customs laws held not to be a "pending suit"); In re Letters Rogatory from First District Judge of Vera Cruz, 36 Fed. 306 (C.C.S.D.N.Y. 1888) (an investigation of smuggling not a "pending suit for recovery of money or property") ; Spanish Consul's Petition, 22 Fed. Cas. 854, No. 13,202 (S.D.N.Y. 1867) (summons to compel testimony before Spanish Consul for use in swindling prosecution denied).

It should be remembered, however, that foreign courts may address their letters rogatory to the State courts, many of which extend full assistance in taking depositions of witnesses within their jurisdictions for use in either civil or criminal actions abroad. For a collection of state statutes authorizing aid to foreign tribunals see 8 WigMone, EVIDENCE § 2195d, n.1 (3d ed. 1940). 
proven so expansive where issuance of American letters was concerned. Indeed, rational consistency seems to have been expressly disavowed, for the attempt of one court to employ that concept to honor a foreign request not complying with Section 701 was promptly overruled. ${ }^{19}$

In 1938 the Federal Rules of Civil Procedure made specific provision for the issuance of letters rogatory in civil actions, but "only when necessary or convenient." 20 And in $19 \pm 6$ the Federal Rules of Criminal Procedure provided authority for issuance of the letters in criminal cases on the motion of a defendant when necessary "to prevent a failure of justice."21 But while the Rules thus replaced the "inherent power" concept with statutory authority to issue letters rogatory, they made no attempt at greater reciprocity in honoring foreign-issued letters.

19. Belding-Corticelli, Ltd. v. Kaufman, 10 F.Supp. 991 (E.D. Pa. 1935), revid sub nom, Janssen v. Belding-Corticelli, Ltd., S4 F.2d 577 (3d Cir. 1936). The district court had granted orders compelling attendance of witnesses before a commissioner named by a Canadian court in which a patent suit was pending. The court, assuming no distinctions between letters rogatory and commissions, reasoned that in the absence of legislative restriction the courts will lend assistance to foreign judiciaries as a matter of cumity. The circuit court overruled this decision, holding that the courts do not have inherent power to compel testimony, but have only the power which they are given by legislation.

See also In re Letters Rogatory from Examining Magistrate of Tribunal of Versailles, France, 26 F. Supp. 852 (D. Md. 1939). Id. at 8545. "From the foint of view of comity it may be said to be unfortunate that our courts are not authorized to aid foreign governments in obtaining testimony in the manner here requested, when such testimony is admissible under their form of jurisprudence. However, this is clearly a matter for Congress, and not for the courts."

20. FED. R. Crv. P., 28(b).

Prior to adoption of the Federal Rules, the Judicial Code provided for depositions de bene esse, to be used to take the testimony of witnesses unable to appear at trials. REr. STaT. $\$ 863$ (1878). They could not, however, be employed outside the United States. Huasteca Petroleum Co. v. United States, 14 F.2d 495 (E.D.N.Y. 1926) ; Cortes v. Tannhauser, 18 Fed. 667 (C.C.S.D.N.Y. 1883). Contra: Bischoffscheim v. Baltzer, 10 Fed. 1 (C.C.S.D.N.Y. 18S2).

The de bene esse statutes which permitted depositions for evidentiary purposes vere replaced by the Federal Rules with their emphasis on permitting depositions to te taken for purposes of discovery, on notice to the opposing parties and without obtaining the permission of the court. FED. $R$. Crv. P., 26-S. The notice procedure vas also made available for parties seeking to take depositions abroad; the only requirement was that the deposition be taken before certain specified consular officers. Depositions on notice have now taken precedence over commissions and letters rogatory. FED. R. Cr: P., 23(b).

21. FED. R. CRrMr. P., 15(a). The Kule states that "If it appears that a prosprective witness may be unable to attend or prevented from attending a trial or hearing, that his testimony is material and that it is necessary to take his deposition in order to prevent a failure of justice, the court at any time after the filing of an indietment or information may upon motion of a defendant and notice to the parties order that his testimony be taken by deposition. ..." Although this subsection of the Rule malies no mention of letters rogatory, subsection (d) orders that depositions be taken in the manner provided in civil actions. The Notes of the Advisory Committee on Rules state that the procedure to be followed is that set forth in Civil Rules 28-31. Fed. R. CRrs. P., 15(d). Consequently, Rule $28(\mathrm{~b})$ of the Civil Rules which authorizes the taking of depositions abroad by notice, commission or letters rogatory is clearly applicable to criminal actions. 
In 1948, however, the revision of the Judicial Code ${ }^{22}$ made a substantial improvement. Section $1782^{23}$ of the new Code authorized the district courts to honor foreign requests for depositions of witnesses "residing within the United States to be used in any civil action pending in any court in any foreign country with which the United States is at peace."24 This Section desirably disposed of the major obstacles to international cooperation in civil suits. But it perpetuated the doctrinal irrationality which has long resulted in discrimination against letters rogatory issued from foreign criminal actions.

The final step in achieving complete reciprocity and doctrinal consistency has now been taken. In May, 1949, Section 1782 was amended to permit federal courts to honor any foreign letters rogatory, civil or criminal, requesting the depositions of any witness within the United States. ${ }^{25}$ Adoption of this amendment at last extends a welcome reciprocity which has long been overdue.

22. Pub. L. No. 773, 80th Cong., 2d Sess. (June 25, 1948).

23. Ibid.;28 U.S.C.A. \$1782 (1948).

24. Ibid. This section repeals the previous restrictive provisions of REv. STAT. $\$ 4071$ (1875), 28 U.S.C. $\$ 701$ (1946).

25. Pub. L. No. 72, 81st Cong., 1st Sess., $\$ 93$ (May 24, 1949). Section 1782 of tho new, Judicial Code, with the changes in italics and the previous wording which has been replaced in brackets, now reads as follows:

"The deposition of any witness [residing] within the United States to be used in any judicial proceeding [civil action] pending in any court in any foreign country with which the United States is at peace may be taken before a person authorized to administer oaths designated by the district court of any district where the witness resides or may be found.

"The practice and procedure in taking such depositions shall conform generally to the practice and procedure for taking depositions to be used in courts of the United States." 28 U.S.C.A. $\$ 1781-2$ (1948). 